\title{
Harmostaxis
}

David J. Perry, K. John Pasi (eds)

\section{Hemostasis and Thrombosis Protocols}

Methods in Molecular Medicine Humana Press, Totowa 1999

XXXIV + $368 \mathrm{pp}$.

ISBN 0-89603-419-4

During the past 5 years molecular analysis of the genetic variation defects that underlie disorders of the clotting system has become standard in many diagnostic coagulation laboratories. Previously this type of analysis was done primarily in the specialized laboratories of large academic centers of thrombosis and hemostasis research. The introduction of DNA analysis in nonacademic laboratories was quickened by the discovery that APC resistance is caused by a single point mutation in the factor $\mathrm{V}$ gene that is easily detectable in an 'idiot proof' PCR assay. This made the less specialized laboratories learn that the common DNA techniques are fairly simple to perform. The book by Perry and Pasi confirms this inkling that with good recipes and kits the DNA analysis of disorders of thrombosis and hemostasis is indeed feasible for many diagnostic laboratories. The book describes in great detail a variety of laboratory protocols aimed primarily at analyzing inherited disorders of the hemostatic system. These protocols vary from simple procedures to detect factor V Leiden and prothrombin 20210 to elaborate techniques for finding mutations in disorders like hemophilia A or protein S deficiency. In addi- tion, sections of the book are devoted to the basic techniques involved in DNA analysis, and to the analysis of platelet disorders. Conceptually, there is no difference between finding mutations in for example the factor VIII, factor IX, antithrombin or protein C gene. Nevertheless, vastly different recipes are described for the analysis of each gene. This is inevitable in a multiauthored book where experts are asked to provide their best techniques. As long as readers realize that the protocol that is given is not necessarily the only way of attacking a particular gene this should not be a problem. Rather, comparison of the different protocols may help readers decide what would be the best approach in their own laboratory. Somewhat more disturbing is the fact that there are many different techniques described for the isolation of DNA from patient samples. These techniques vary from simple saltingout techniques to more elaborate phenol extractions. One author advises to handle the blood samples in a class II cabinet using double gloves, apron and goggles. I expect that some diagnotic laboratories frown at such recommendations. It would have been helpful if the authors had attempted to provide guidelines for making a wise and convenient choice with respect to DNA isolations.

In summary, this is a useful book for those attempting to introduce or maintain DNA analysis in their laboratory. The book would have benefited from more forceful editing, but in particular laboratory technicians may find many useful suggestions to improve their work.

\section{P.H. Reitsma, Leiden}

\begin{tabular}{ll}
\hline KARGER & ( 2000 S. Karger AG, Basel \\
Fax +4161301-0147/99/0295-0300\$17.50/0 \\
$\begin{array}{l}\text { E-Mail karger@karger.ch } \\
\text { www.karger.com }\end{array}$ & $\begin{array}{l}\text { Accessible online at: } \\
\text { www.karger.com/journals/hae }\end{array}$
\end{tabular}

